ORIGINAL ARTICLE

\title{
Serum Zinc Levels in Children with Upper Respiratory Tract Infection in the Age of 2-12 Years in Pakistan
}

\author{
MADEEHA REHMAN ${ }^{1}$, LUBNA AMAN ${ }^{2}$, MUHAMMAD SHAHID GHAFFAR ${ }^{3}$, MUQADAR SHAH $^{4}$, ZARMAST KHAN ${ }^{5}$, \\ SAJID SHAMIM ${ }^{6}$ \\ ${ }^{1,2}$ Pediatrician, Peads Medicine Dr. Amanaullah Baloch Clinic Muhabbat Nagar, Malir, Karachi \\ ${ }^{3}$ Assistant Professor of Paediatric, Hamdard University hospital, Karachi \\ ${ }^{4}$ Assistant Professor Pediatrics, PIMS Children Hospital, Islamabad \\ ${ }^{5}$ Assistant Professor Pediatrics, Shifa College of Medicine, Islamabad \\ ${ }^{6}$ Assistant Professor Paediatric Department, Frontier Medical and Dental College, Abbottabad \\ Corresponding author: Dr. Madeeha Rehman, Email: madeeharehmn@gmail.com, Cell no. 03312201404
}

\begin{abstract}
Objective: The aim of this study is to determine the zinc levels in children with upper respiratory tract infection in the age of 2-12 years in Pakistan.

Study Design: A prospective observational

Place and Duration: Conducted at department of Paediatrics Hamdard University hospital, Karachi and PIMS Children Hospital, Islamabad for four months duration from October, 2020 to January, 2021.

Methods: Total 90 children of both genders were presented in this study. Patients' detailed demographics including age, sex, socio-economic class and maternal education were recorded after taking informed written consent from the authorities. Patients with upper respiratory tract infection were included. Mean serum zinc among children was calculated as $55.14 \pm 17.68 \mu \mathrm{g} / \mathrm{dl}$. Outcomes were measured in terms of risk factors associated with URT and lower level of serum zinc among patients. Complete data was analyzed by SPSS 24.0 version.

Results: There were 60 (66.7\%) males and 30 (33.3\%) were females. Mean age of the cases were $08.44 \pm 7.65$ years. $62(68.9 \%)$ patients were from lower socio economic status and literacy rate of mothers were 35 (38.9\%).Symptoms of URTI were cough, sore throat, runny nose and headache. Previous family history of URTI found in $55(61.1 \%)$ cases. Rhinovirus was the most common cause of URTI found in $70(77.8 \%)$ cases. Severity of cold was found among $18(20 \%)$ children. Meanserum zinc was38.76 $\pm 6.88 \mu \mathrm{g} / \mathrm{dl}$ and found among 87 (96\%) cases.

Conclusion: We concluded in this study that the zinc level was significantly lower among children who had rhinovirus due to severe cold.
\end{abstract}

Keywords: Serum Zinc Level, Children, Upper Respiratory Tract Infection

\section{INTRODUCTION}

There are various elements of cell metabolism where zinc is involved. For catalytic activity, zinc is required by around 100 enzymes. It's crucial for immunological function, protein synthesis, wound healing, antioxidation, DNA synthesis, and cell division, to name a few functions. During lung inflammation and injury, it also protects the respiratory cells' integrity. There is an increased risk of stunted growth, diarrheal illnesses and respiratory tract infections in children with zinc insufficiency (Zinc deficiency). [1]

Zinc absorption occurs mostly in the jejunum, where it is carried by Zip4. [1,2] Metallothionein and cysteine-rich proteins help in its absorption through passive diffusion or by attaching to the apical membrane of enterocytes. [3,4]

After other symptoms of a cold have subsided, coughing and nasal discharge may continue for up to 14 days. [5] There are several acute upper respiratory tract infections (URTIs) that are commonly referred to as a common cold (though bronchi are generally classified as part of the lower respiratory tract.) Cough, sore throat, runny nose, nasal congestion, headache, low-grade fever, facial pressure, and sneezing are frequent symptoms of URTIs. [6]

Rhinovirus symptoms in children usually appear 1-3 days following exposure to rhinovirus. 7-10 additional days are usually required to recover from the illness. [5]
Yellow, thick, or green mucous discharge is a natural course of viral URTI and does not require antibiotic treatment. An otitis media infection causes pain and pressure in the middle ear, while viral conjunctivitis causes reddening of the eye. In many cases, [7] are connected with urinary tract infections. Rhinovirus infection mirrors the immune response in terms of pathogenesis. In the upper respiratory tract, the viruses do not harm the cells, but they do alter the tight connections of epithelial cells. Innate and adaptive immune responses are triggered as a result of this. [8] Oral and pharyngeal infections have been linked to sexually transmitted infections. [9] Each year, children suffer from two to nine viral respiratory diseases. 18 and a half billion URTIs were reported in 2013. There were approximately 3,000 fatalities in 2014 , down from 4,000 deaths in 1990. [11] Acute respiratory infections (URIs) are the most frequent infectious disease among adults in the United States, and they are a primary cause of absence from work and school.

Children with ALRI have not been examined in the Gambia and Burkina Faso in West Africa, despite some interventional trials on zinc supplementation. [12,13] In addition, while some sections of Nigeria have conducted studies on blood zinc levels in children, there are very few studies that specifically target ALRI children. [14] 


\section{MATERIAL AND METHODS}

This prospective observational study was conducted at of Paediatrics Hamdard University hospital, Karachi and PIMS Children Hospital, Islamabad for four months duration from October, 2020 to January, 2021. The study comprised of 90 children. Patients' detailed demographics were recorded after taking in formed written consent. Patients greater than 12 years and those had any other medical illness were excluded from this study.

Patients were aged between 2-12 years. Patients with upper respiratory tract infection were included. Mean serum zinc among children was calculated as $55.14 \pm 17.68 \mu \mathrm{g} / \mathrm{dl}$. Outcomes were measured in terms of risk factors associated with URT and lower level of serum zinc among patients. Complete data was analyzed by SPSS 24.0 version.

\section{RESULTS}

There were $60(66.7 \%)$ males and 30 (33.3\%) were females. Mean age of the cases were $08.44 \pm 7.65$ years. 62 $(68.9 \%)$ patients were from lower socio economic status and literacy rate of mothers were 35 (38.9\%). Symptoms of URTI were cough, sore throat, runny nose and headache. Previous family history of URTI found in 55 (61.1\%) cases.(Table 1)

Table 1: Baseline details demographics of enrolled cases

\begin{tabular}{|l|l|l|}
\hline Variables & Frequency & $\%$ \\
\hline Mean age (years) & $08.44 \pm 7.65$ & \multicolumn{1}{|l|}{} \\
\hline Gender & 60 & 66.7 \\
\hline Male & 30 & 33.3 \\
\hline Female & 28 & 31.1 \\
\hline Socio-Economic status & 68.9 \\
\hline High & 62 & 38.9 \\
\hline Low & 61.1 \\
\hline Literacy & 35 & 44.4 \\
\hline Yes & 55 & 27.8 \\
\hline No & 40 & 21.1 \\
\hline Symptoms & 40.7 \\
\hline Cough & 25 & 6.1 \\
\hline Sore throat & 19 & 61.1 \\
\hline Runny nose & 6 & 38.9 \\
\hline Headache & 55 \\
\hline Previous History & 35 \\
\hline Yes & \multicolumn{2}{|l|}{} \\
\hline No &
\end{tabular}

Table 2: Clinical profile of children with URTI

\begin{tabular}{|l|l|l|}
\hline Variables & Frequency & \%age \\
\hline Virus & 70 & 77.8 \\
\hline rhinovirus & 45 & 50 \\
\hline influenza & 32 & 35.6 \\
\hline adenovirus & 18 & 20 \\
\hline enterovirus & 12 & 13.3 \\
\hline respiratory syncytial virus & 18 & 20 \\
\hline Cold & 72 & 80 \\
\hline Severe & \multicolumn{2}{|l}{} \\
\hline Normal
\end{tabular}

Rhinovirus was the most common cause of URTI found in $70(77.8 \%)$ cases, influenza found in $45(50 \%)$ cases, adenovirus in 32 (35.6\%), enterovirus in $18(20 \%)$ and respiratory syncytial virus was among 12 (13.3\%).
Severity of cold was found among 18 (20\%) children. (Table 2)

We found that mean serum zinc was $38.76 \pm 6.88 \mu \mathrm{g} / \mathrm{dl}$ which was significantly lower and found among 87 (96\%) cases. Except this Low albumin $40.41 \pm 4.88 \mathrm{~g} / \mathrm{l}$, low Serum protein $47.64 \pm 0.77 \mathrm{~g} / \mathrm{l}$ and low Serum CRP 33.24 \pm 4.29 $\mathrm{mg} / \mathrm{l}$ were observed among these cases. (Table 3 )

Table 3: Prevalence of low serum zinc level and the other factors among enrolled cases

\begin{tabular}{|l|l|l|}
\hline Variables & Frequency $(\mathrm{n}=90)$ & $\%$ age \\
\hline Low Serum Zinc $(\mu \mathrm{g} / \mathrm{dl})$ & $38.76 \pm 6.88$ & - \\
\hline Low albumin $(\mathrm{g} / \mathrm{l})$ & $40.41 \pm 4.88$ & - \\
\hline low Serum protein $(\mathrm{g} / \mathrm{l})$ & $47.64 \pm 0.77$ & - \\
\hline low Serum CRP $(\mathrm{mg} / \mathrm{l})$ & $33.24 \pm 4.29$ & - \\
\hline Low Serum Zinc & 87 & 96 \\
\hline Yes & 3 & 4 \\
\hline No &
\end{tabular}

\section{DISCUSSION}

Common throughout the winter months, upper respiratory infections (URIs) can have a negative impact on quality of life for a few weeks. Pneumonia, meningitis, sepsis, and bronchitis may occur in some individuals. A URI is responsible for a few deaths each year. Work and school vacations are typical occurrences. Furthermore, patients spend billions of dollars on ineffective therapies. No treatment has been proven to reduce the duration of a viral upper respiratory infection. As a result, although the vaccine is only effective in $40-60 \%$ of individuals, at most.[15] In this prospective study 90 children were presented with mean age $08.44 \pm 7.65$ years. Most of the cases $66.7 \%$ were males and the rest were females. According to socio-economic status $68.9 \%$ cases had low status and most of the mothers were illiterate $61.1 \%$. These findings were comparable to the previous studies.[16,17]

In current study cough, sore throat, runny nose and headache were the symptoms. Previous family history of URTI found in $55(61.1 \%)$ cases.[15] Rhinovirus was the most common cause of URTI found in $70(77.8 \%)$ cases, influenza found in $45(50 \%)$ cases, adenovirus in 32 $(35.6 \%)$, enterovirus in $18(20 \%)$ and respiratory syncytial virus was among 12 (13.3\%). Severity of cold was found among $18(20 \%)$ children. These results showed resemblance to the many previous studies.[19-21] "Modest but persistent" benefit of vitamin $\mathrm{C}$ prophylaxis at doses of 0.2 grams or more on duration and severity of common cold symptoms was found in a Cochrane Review[22] (8 percent and 13 percent decreases in duration for adults and children, respectively). A high dose of vitamin $\mathrm{C}$, on the other hand, has not been proven to be effective in clinical trials when taken therapeutically after the onset of symptoms.

We found that mean serum zinc was $38.76 \pm 6.88 \mu \mathrm{g} / \mathrm{dl}$ which was significantly lower and found among 87 (96\%) cases. It is consistent with past data from India and Bangladesh that zinc levels in the serum of ALRI patients were lower than those in controls.[23,24] Serum zinc levels were substantially higher in the control group (p0.01) than in the pneumonia patient group, according to Arica et al [25]. Among Sri Lankan pre-school children, Hettiarachchi $M$ et al [26] found that 38.3 percent had both vitamin $A$ and zinc deficits. Children with protein energy deficiency were 
studied by Singla PN et al [27]. In children with severe malnutrition, zinc and copper levels were found to be considerably low (grades III and IV PEM). Height-forage showed a substantial positive connection (p0.001).

The link between dietary status, vitamin A and zinc levels, and oxidative stress in patients with ataxiatelangiectasia was also examined in da Silva $R$ et al's study.[27] Compared to the control group, ataxiatelangiectasia patients had high malnutrition rates and low lean body mass, according to research published by the authors. Ataxia-telangiectasia (AT) patients, on the other hand, had zinc levels equivalent to those of the control group. Vitamin A and zinc levels in AT patients were unchanged. It was determined that there was a relationship between zinc and copper levels in preterm newborns by Sharda B et al [28].

\section{CONCLUSION}

We concluded in this study that the zinc level was significantly lower among children who hadrhinovirus due to severe cold.

\section{REFERENCE}

1. Tuerk MJ, Fazel N. Zinc deficiency. Curr Opin Gastroenterol. 2009;25(2):136-43.

2. Sandstead $\mathrm{HH}$. Understanding zinc: recent observations and interpretations. J Lab Clin Med. 1994;124(3):322-7

3. Liuzzi JP, Cousins RJ. Mammalian zinc transporters. Annu Rev Nutr. 2004;24:151-72.

4. De Raeve HR, Thunnissen FB, Kaneko FT, Guo FH, Lewis M, Kavuru MS, et al. Decreased Cu,Zn-SOD activity in asthmatic airway epithelium: correction by inhaled corticosteroid in vivo. Am J Physiol. 1997;272(1 Pt 1):L148-54

5. Rhinitis Versus Sinusitis in Children" (PDF). Centers for Disease Control and Prevention. Archived (PDF) from the original on 16 February 2017. Retrieved 19 December 2016. (8) This article incorporates text from this source, which is in the public domain.

6. Infections of the Respiratory System". Chapter 93: Infections of the Respiratory System. National Center for Biotechnology Information, U.S. National Library of Medicine. University of Texas Medical Branch at Galveston. 1996. ISBN 9780963117212. Retrieved 10 July 2021.

7. "Conjunctivitis". The Lecturio Medical Concept Library. 23 July 2020. Retrieved 10 July2021.

8. Pokorski M (2015). Pulmonary infection. Cham: Springer. ISBN 978-3-319-17458-7.

9. Human papillomavirus (HPV) and Oropharyngeal Cancer, Sexually Transmitted Diseases". Centers for Disease Control and Prevention. 4 November 2016. Archivedfrom the original on 16 December 2016. Retrieved 19 December 2016.

10. Global Burden of Disease Study 2013 Collaborators (August 2015). "Global, regional, and national incidence, prevalence, and years lived with disability for 301 acute and chronic diseases and injuries in 188 countries, 1990-2013: a systematic analysis for the Global Burden of Disease Study 2013". Lancet. 386 (9995): 743-800.

11. Lozano R, Naghavi M, Foreman K, Lim S, Shibuya K, Aboyans $\mathrm{V}$, et al. (December 2012). "Global and regional mortality from 235 causes of death for 20 age groups in 1990 and 2010: a systematic analysis for the Global Burden of Disease Study 2010". Lancet. 380 (9859): 2095-128.

12. Bates CJ, Evans PH, Dardenne M, Prentice A, Lunn PG, Northrop-Clewes CA, et al. A trial of zinc supplementation in young rural Gambian children. Br J Nutr. 1993;69(1):243-255.
13. Muller $\mathrm{O}$, Garenne $\mathrm{M}$, Reitmaier $\mathrm{P}$, Van Zweeden $\mathrm{AB}$, Kouyate $B$, Becher $\mathrm{H}$. Effect of zinc supplementation on growth in West African children: a randomized double-blind placebo-controlled trial in rural Burkina Faso. Int J Epidemiol. 2003;32(6):10981102

14. Abiodun OA. Summary of workshop on clinical experience of micronutrient deficiency in children 0-5 years in Nigeria delivered at the 39th Paediatric Aociation of Nigerian Conference, Lago. 2008:1-64.

15. Thomas M, Bomar PA. Upper Respiratory Tract Infection [Updated 2021 Jun 30]. In: StatPearls [Internet]. Treasure Island (FL): StatPearls Publishing; 2021 Jan-. Available from: https://www.ncbi.nlm.nih.gov/books/NBK532961

16. Rerksuppaphol S, Rerksuppaphol L. A randomized controlled trial of zinc supplementation in the treatment of acute respiratory tract infection in Thai children. Pediatr Rep. 2019;11(2):7954. Published 2019 May 23.

17. Ibraheem RM, Johnson AB, Abdulkarim AA, Biliaminu SA. Serum zinc levels in hospitalized children with acute lower respiratory infections in the north-central region of Nigeria. Afr Health Sci. 2014;14(1):136-142. doi:10.4314/ahs.v14i1.21

18. Fashner J, Ericson K, Werner S. Treatment of the common cold in children and adults. Am Fam Physician. 2012 Jul 15;86(2):153-9.

19. Harper SA, Bradley JS, Englund JA, File TM, Gravenstein S Hayden FG, McGeer AJ, Neuzil KM, Pavia AT, Tapper ML, Uyeki TM, Zimmerman RK., Expert Panel of the Infectious Diseases Society of America. Seasonal influenza in adults and children--diagnosis, treatment, chemoprophylaxis, and institutional outbreak management: clinical practice guidelines of the Infectious Diseases Society of America. Clin Infect Dis. 2009 Apr 15;48(8):1003-32.

20. Tonkin-Crine SK, Tan PS, van Hecke O, Wang K, Roberts NW McCullough A, et al. (September 2017). "Clinician-targeted interventions to influence antibiotic prescribing behaviour for acute respiratory infections in primary care: an overview of systematic reviews". The Cochrane Database of Systematic Reviews. 9: CD012252.

21. Reveiz L, Cardona AF (May 2015). "Antibiotics for acute laryngitis in adults". The Cochrane Database of Systematic Reviews (5): CD004783.

22. Douglas RM, Hemilä H, Chalker E, Treacy B. Vitamin C for preventing and treating the common cold. Cochrane Database Syst Rev. 2007 Jul 18;(3):CD000980

23. Shakur MS, Malek MA, Bano N, Islam K. Zinc status in well nourished Bangladeshi children suffering from acute lower respiratory infection. Indian Pediatr. 2004;41(5):478-481

24. Shakur MS, Malek MA, Bano N, Rahman M, Ahmed M. Serum and hair zinc in severely malnourished Bangladeshi children associated with or without acute lower respiratory infection. Indian J Pediatr. 2009;76(6):609-614

25. Arica S, Arica V, Hüseyin Dag, et al. Serum zinc levels in children of 0-24 months diagnosed with pneumonia admitted to our clinic. Int J Clin Exp Med. 2011; 4: 227-233.

26. Hettiarachchi $M$, Liyanage C. Coexisting micronutrient deficiencies among Sri Lankan pre-school children: a community-based study. Matern Child Nutr. 2012; 8: 259-266.

27. Da Silva R, Dos Santos-Valente EC, Burim Scomparini F, Saccardo Sarni RO, Costa-Carvalho BT. The relationship between nutritional status, vitamin $A$ and zinc levels and oxidative stress in patients with ataxia-telangiectasia. Allergol Immunopathol (Madr). 2014; 42: 329-335.

28. Sharda B, Adhikari R, Ajmera M, Gambhir R, Singh PP. Zinc and copper in preterm neonates: relationship with breast milk. Indian J Pediatr. 1999; 66: 685-695. 